\title{
Gender and Eroticism in Contemporary Art from South Africa
}

\author{
ANETA PAWŁOWSKA \\ University of Lodz \\ Katedra Historii Sztuki \\ Wydział Filozoficzno-Historyczny \\ Uniwersytet Łódzki \\ ul. Narutowicza 65 \\ 90-131 Łódź, Poland \\ aneta.pawlowska@uni.lodz.pl
}

\begin{abstract}
The aim of this article is to present the interaction between the history of lesbian and gay culture and its identity on the one hand, and the connection between the visual art or visual culture on the other hand. This essay endeavors to interpret the different meanings attached to sexual identities by examining the diverse artistic activities of a variety of artists: both men and women (e.g. Steven Cohen, Clive van den Berg, Andrew Verster, Nicolas Hlobo, Jean Brundrit, Zanele Muholi). Employing an intersectional analytical approach, the article shows that the identity of art is constructed alongside a person's multiple identities, such as race, gender, family ties, religion and class.

The main research question is whether in today's visual art originating from South Africa, which is characterized by a hegemony of heterosexual stereotypes, there is a significant place for gender oriented art?
\end{abstract}

Keywords: South Africa; gender; LGBTI; feminism visual art; photography 
The year 1994 constitutes a clear demarcation line in the cultural and artistic life of the black and white community in the Republic of South Africa. 1994 is the year celebrated worldwide as the day of the termination of apartheid ${ }^{1}$ in South Africa, the year of the first general parliamentary elections and the first presidential elections won by Nelson Mandela - the first black president in the history of the Republic of South Africa. Soon after these events the new ruling party announced an official programme aimed at constructing a multiracial "rainbow nation." An intensive period of political transition began but it also encompassed a social revolution of this predominantly puritan and ultra conservative country. Politicians today often emphasize the advantages flowing out from the cultural differentiation of the society and from various different experiences of individual ethnic groups.

Simultaneously a previously completely unknown phenomenon of broad inclusion of black artists in the South African Art world appeared. After the dissolution of various totalitarianisms associated with apartheid rule, such art topics, as feminism, eroticism, gay/lesbian art and gender problems, which were formerly almost eliminated from literature about art (e.g. monumental books written by Esmé Berman (Berman 1973, 1993 2), have become important elements of the present day cultural life of South Africa. The social changes evident in post-apartheid South Africa make it necessary for many theorists to re-examine today how sexual identity is shaped within this context.

This article explores these new politics of gender and female sexuality in post-apartheid South Africa by focusing on cultural representations of lesbians, particularly within a visual culture. I would like to show the intersection between the history of lesbian and gay culture and identity on the one hand, and between the conceived visual art or visual culture on the other hand. This essay endeavours to interpret the different meanings attached to sexual identities by examining the diverse artistic activities of a variety of artists: both men and women. Employing an intersectional analytical approach, I would like to show that art identity is constructed alongside a person's multiple identities, such as race, gender, family ties, religion and class. How can South African women and men artists rework problems with gender, sexuality, and intimacy in a context of socioeconomic marginalization, persisting gender inequalities, and climbing

\footnotetext{
${ }^{1}$ This constitutional and political formation of rule lasted for nearly 46 years in the period between 1948 and 1994. During this time, the white community - accounting for about $15 \%$ of the total population - through consecutive legal acts, secured complete and utter domination in all spheres of life, both economic and political. This situation allowed the white minority full control over the black people, even outside their places of residence, concerning practically all private matters in human life, among other things the conclusion of marriages.

${ }^{2}$ Only in her last book published in 2010 - a biography of famous artist Alexis Preller, E. Berman mentions Preller's homosexuality (Berman 2010:123).
} 
HIV infection rates. And what does it mean to be a lesbian or gay artist or just a woman artist in South Africa today?

According to Marlene Arndt and Gideon de Bruin, legislation prior to democracy "denied lesbians and gay men their basic human rights and reduced them to social outcasts and criminals" (Arndt and Bruin 2006: 16). In 1996 post-apartheid South Africa became the very first country in the world that explicitly incorporated lesbian and gay rights within the Bill of Rights (South African Social Attitudes... 2006: 20). Since then, the discussion concerning human sexuality and proclamation of sexual identities has increasingly evolved. This has brought about not only the subject of rights but also the question of gender relations and cultural authenticity, as visible, for example, in the emerging populist notion of homosexuality as "un-African," ${ }^{3}$ into the focus of the nation-states' politics. A similar discourse exists among Afrikaners, maintaining that homosexuality is foreign to, and inconsistent with, true Afrikaner identity (Croucher 2002: 316). On November $14^{\text {th }}$, 2006 South Africa legalized same-sex marriage which means, that RSA is the only African country where same-sex marriage is recognized and accepted. Thus, South Africa declared itself the most tolerant in the sexual politics context African country in today's contemporary society. Nevertheless, Shereen Pandit in the article entitled Women and Oppression in South Africa, stated:

Violence against women takes place at all levels in society - but it is the screams from the townships and squatter camps where poor black women live, that are never heard. I mean that quite literally. It has been reported that one woman suffered rape throughout the night in a shantytown whilst neighbours were too fearful to intervene. They knew that calling the police was no good, assuming they could find the means to call the police. Poor black women are invisible. This is as true today as it was before 1994. (Pandit 2002: 72)

\section{Historical context for feminism and gender problems in South Africa}

In South African context a great number of scientists emphasize the problems of feminism together with LGBTI (Lesbian Gay Bisexual Transsexual Intersex)

\footnotetext{
${ }^{3}$ A very public example of the claim that "homosexuality is un-African" was put forth by Winnie Mandela (the ex-wife of the former president of the country Nelson Mandela) during her 1991 kidnapping and assault trial (Ratele and Duncan 2003: 276-277). Another example occurred in 2012, when the Congress of Traditional Leaders of South Africa (CONTRALESA) filed a draft resolution to the National Assembly, calling for the removal of the prohibition on the basis of sexual orientation from the Constitution, citing homosexual activities as "un-African" (SAPA 2012). To see more Gunkel (2010: 25-51).
} 
group problems. ${ }^{4}$ Not only the heterosexual women but also the LGBTI minority could be regarded as subordinated by the dominant heterosexual male community during the apartheid era, and they were both treated rather as victims than true political subjects. For instance Mark Hunter contends that observers should understand contemporary sexual practices and relationships in South Africa as influenced by the "dialectic relationship between political economy and intimacy" (Hunter 2010: 5). In this dialectical process, sex, love, and intimacy in post-apartheid South Africa have been transformed, in complex ways, by the vagaries of colonial and apartheid capitalism and a neoliberal democracy.

With the growing Afrikaner nationalist movement of the 1900s, Dutch Reform Calvinism became a major foundation of apartheid and nationalist Afrikaner ideology. The minority government believed they were ordained to civilize South Africa. According to religious ideology of Calvinism, a woman must submit to the dominance of a man (Jordaan 1987: 42-43) and homosexuality was unnatural and immoral. Therefore, it is safe to assume that the nationalist government would have taken both anti-feminist and an anti-homosexuality stance, which would have influenced policy. This paternalistic view stems from the extremist Afrikaner understanding of Christianity (Thompson 2001: 51-52, 145). As a result, any opposition to their role and superiority would be met with harsh repercussion. The government believed that the only way to achieve this utopia would be to control every aspect of public life.

One can assume that the women of South Africa did not make too many attempts to attain subversive and revolutionary goals. ${ }^{5}$ Predominantly their attitude was characterized by a large degree of passiveness and the acceptance of the prevailing system of patriarchate. As Olabisi Aina (1998: 75), a social scientist, points out: “[...] African women, unlike their Western sisters, are struggling not just to attain political power but also to be empowered by gaining access to a good education and the professions, among other things. Many of the issues which are of concern to the African feminist are often left out of the Western feminist agenda."

One of the earliest women organizations in South Africa was The Bantu Women's League founded in 1913. In the 1950s, various other organizations devoted specifically to women were formed, such as the ANC Women's League (ANCWL) or the Women's Council within the South West Africa People's

\footnotetext{
${ }^{4}$ Recently we can note an extension of the term LGBTI in order to include other sexual minority groups into a new term LGBTQQIA, which stands for Lesbian, Gay, Bisexual, Transgender, Queer, Questioning, Intersex and Allied <http://time.com/3599950/intersex-meaning/>, 02.05.2017.

${ }^{5}$ A strong women action was staged on August $9^{\text {th }} 1956$ when over 20000 women of all races, led by Rahima Moosa, Ngoya, Williams-de Bruyn and Helen Joseph, marched through the streets of Pretoria to the Union Buildings to hand over bundles of petitions with more than 100000 signatures against the new pass laws and the Group Areas Act to then South African prime minister, JG Strijdom.
} 
Organization (SWAPO). In April 1954, was founded a more global Federation of South African Women (FSAW or FedSAW) with the objective to struggle against racism and oppression of women, as well as to make African women understand that they have rights both as human beings and as women. ${ }^{6}$ Another instance of a non-violent resistance organization was the Black Sash, which was founded on May $19^{\text {th }} 1955^{7}$ by 6 white women. Many members of the Black Sash were vilified within their local white communities, and it was not unusual for women wearing the black sash to be physically attacked by supporters of apartheid. Thus the problem which posed a much greater challenge for the liberal section of the society, than only the need for the emancipation of women, was the struggle against the system of racial segregation.

During this period it was obvious that there existed a strict and absolute prohibition of contacts of erotic nature between persons of different races. The world of apartheid undertook a cruel game in which the stake was not only to gain complete domination of Western culture but also the cultivation of ethnical identity of white people in Africa, which are both strongly integrated. The founders of apartheid unconsciously used the main idea of Michael Foucault, who stated that the existence of "the Others" - is the necessary element for unification of a society and for the creation of a common cultural system (Owens 1998: 421-451). And this is precisely how the white Afrikaners saw their main duty and obligation to the nation. All this suggests that the distinct need for domination arises in fact from the anxieties and fears of losing homogeneity and cultural domination of the European civilization. Notable among such situations, writes Anne Nasimiyu-Wasike, is the subjugated status of women in "patriarchal dominated societies" (Nasimiyu-Wasike 2004: 102). Similarly Bernadette Mbuy-Beya ${ }^{8}$ elaborates upon the social and ecclesial implications of the struggle "for the liberation of women," against multiple forms of violence and deprivation (Mbuy-Beya 2005: 166); while Roxanne Jordaan and Thoko Mpumlwana criticize both - the racial and "gender apartheid" in the society and in churches (Jordaan and Mpumlwana 2015: 164).

After the abolishment of apartheid in 1994, the situation of women in South Africa underwent considerable improvement. Women of today already attain quite significant successes in politics, especially the women who became actively

\footnotetext{
${ }^{6}$ FSAW and ANCWL organised bus boycotts, campaigns against restrictive passes in 1956 in Pretoria and in Sharpeville in 1960.

${ }^{7}$ Between 1955 and 1994, the Black Sash provided widespread and visible proof of white resistance towards the apartheid system. Its members worked as volunteer advocates to families affected by apartheid laws; held regular street demonstrations; spoke at political meetings; brought cases of injustice to the attention of their Members of Parliament, and kept vigils outside Parliament and government offices.

${ }^{8}$ Bernadette Mbuy-Beya a Roman Catholic religious sister from Congo (formerly Zaire).
} 
engaged in politics quite early on and bound themselves with the victorious black party, African National Congress (ANC). Best examples are Winnie Mandela - the ex-wife of President Nelson Mandela or Frene Ginwala or Albertine Sisulu (the wife of the well-known politician from the ANC). However the traditional upbringing of girls in the dominating system of patriarchate still reaps its harvest. Black women still comply with the old tradition of the so called lobola - which means that they are purchased by their future husbands from their fathers for the equivalent of several pieces of cattle. They accept the constant infidelity of their husbands, excused by the still quite common separation of families, forced by the local economic situation. They agree to sexual practices, which are dangerous for their health: for example, the so called tradition of "dry sex," and the absence of any protection against pregnancy or AIDS. According to statistics, one of every three women in South Africa was in an abusive relationship in 2012. A woman was killed by her partner every six days, and there was a rape every 35 seconds in 2012 (Essof 2012).

An even greater tragedy which is occurring in the present-day South Africa is the widespread brutality of rape, performed by men, who are generally convinced that women are inferior creatures to them and completely dependent. Moreover there is a widespread myth in Africa, that "rape is cure for AIDS" (Itano 2003). This tragic myth results in frequent brutish and savage rapes, often performed on little girls and female babies, even as young as three months old (Epstein and Jewkes 2009: 1419; Itano 2003: 4). Another important problem is the very high crime rate, due to large unemployment among black people and the lack of life perspectives (Itano 2003: 4; Lewis 1994). Women's land and housing rights are still limited and insecure. Too many women continue to live in poverty.

The apartheid government was hostile to the human rights of LGBT South Africans. Homosexuality was a crime punishable by up to seven years in prison; this law was used to harass and outlaw South African gay community events and political activists. Sexual intercourse between men was historically prohibited in South Africa as the common law crimes of "sodomy" and "unnatural sexual offences," inherited from the Roman-Dutch law (Goodman 2001: 718-728). A 1969 amendment to the Immorality Act prohibited men from engaging in any erotic conduct when there were more than two people present (Botha and Cameron 1997: 23-26). However homosexuality was a common occurrence in the gold mines of South Africa during the 1950s and 1960s (and even now) (Moodie et al. 1988). The men interviewed argued that in fact they are heterosexual. They explained that they were isolated from their wives and felt lonely, so they took young boys as their "wives" 9 (Moodie et al. 1988).

\footnotetext{
${ }^{9}$ A similar tradition of amachicken takes place in a girls-only boarding school, an institutionalized female homosocial environment (Ratele and Duncan 2003: 279).
} 
It should be also mentioned that white homosexual men were relatively well-off when compared to other homosexual groups. Gevisser (1995: 16-17) argues that homosexual, middle/upper-class white people were able to mobilize a homosexual movement first because they had enough financial and political clout supporting them to achieve a minor victory for homosexual activism. However the white homosexual man, like most homosexuals in the apartheid state, were seen as subversive and a threat to national security (Elder 1995: 56-57). This period was documented by Hugh MacFarlane, an amateur photographer. During the late 1950s into the 1970s, he (presumably starting as a hobby) took images of young men, mostly naked. According to Storm Janse van Rensburg the importance of these images as an early document of South African white gay male experience and imaging "must be emphasized, particularly as a reclaiming exercise" (Van Rensburg 2004). These photographs were distributed through an informal network of middle class gay men in the bigger cities. MacFarlane was also known in certain circles as the "Pornogravin" (Porno Duchess). He took images of what some believed were also his lovers. Proof exists that he advertised in European and American "beefcake periodicals" and distributed images internationally through catalogue sales. Given the apartheid regime's position on homosexuality and its associated cultures, this was a dangerous pastime. Today some South African artists like Steven Cohen and Hentie van der Merwe have made use of MacFarlane's imagery to the benefit of their own creative output (Van Rensburg 2004).

In the 1970s-1980s, LGBT activism was among the many human rights movements in South Africa, with some groups only dealing with LGBT rights and others advocating for a broader human rights campaign. Despite legal restrictions, several South African gay rights organizations formed in the late 1970s, during the time when the ruling National Party strengthened the national sodomy law in 1976. However, until the late 1980s gay organizations were often divided along racial lines and the larger political question of apartheid. The Gay Association of South Africa (GASA), based in the Hillbrow district in central Johannesburg, was a predominantly white organization that initially avoided taking an official position on apartheid, while the Rand Gay Organization was founded in 1986 as being multi-racial and in opposition to the racist political system of apartheid (Cock and Bernstein 2002: 128-129).

Most LGBT people had to maintain a certain level of secrecy. During the apartheid period gay life and culture took place behind closed doors. Homosexual people would go to clubs that catered exclusively to them, or had to organize parties at their homes. LGBT formed communities in places like District Six in Cape Town, and Sophiatown in Johannesburg. Urban areas also offered homosexuals from townships more freedom, to be away from judgmental parents and 
communities, and to live around people who shared similar life experiences and who were accepting of them (Gevisser 1995: 16-17). Since apartheid ended, President Nelson Mandela's government has pushed to end all forms of discrimination. His successor Thabo Mbeki went even further to support the fight for LGBTI rights in other African countries. ${ }^{10}$ The current South African president Jacob Zuma is an outspoken homophobe, however despite his vocal homophobia, he has given his support to the constitutional LGBTI rights ("Jacob Zuma Gives Cautious Support..." 2012). In 1994, male same-sex conduct was legalized, at this point it should be mentioned that female same-sex conduct had never been illegal (similarly as in other former British colonies) (To see more: Livermon 2013.)

Generally speaking it can be said that conservative social attitudes among both white and black populations in South Africa are rather traditionally critical to homosexuality; such attitudes have persisted also to some degree in post-Apartheid society. ${ }^{11}$ It should also be mentioned that since 1994, a number of scholarly monographs on "queer" South African sexuality, as well as female sexuality and feminism problems have emerged. In January 1991 the Gender Research Group at the University of Natal organized a conference concerning Women and Gender in South Africa. In 1995 a milestone in LGBTI studies was achieved - the "First Southern African Colloquium on Gay and Lesbian Studies" at the University of Cape Town. All of the publications and conferences tried to clarify and analyze the topic which Sylvia Tamale refers to as "African sexualities" (Tamale 2011). The most important publications which undertake the task to recapitulate this subject are these critical books: Neville Hoad's influential African Intimacies: Race, Homosexuality, and Globalization (2007), which analyzes the vexed relationship between the concepts of racial authenticity and homosexuality, too often seen as incompatible, and Brenna Munro's meticulously researched South Africa and the Dream of Love to Come: Queer Sexuality and the Struggle for Freedom (2012), which reads South African history queerly, examining how gay people

\footnotetext{
${ }^{10}$ An apparent tolerance of gays and lesbians in South Africa during Nelson Mandela's and Thabo Mbeki's presidency, contrasts sharply with the widespread and official homophobia and oppression of gays in the neighbouring states of Zimbabwe and Namibia. President Mugabe of Zimbabwe has compared homosexuals to dogs and pigs, and argued that they should not have any rights at all. Namibia's President Nujoma vilifies homosexuals as a "foreign influence with corrupt ideology" attempting to "exploit the country's democracy"(Croucher 2002: 316).

${ }^{11}$ According to South African Social Attitudes Survey (SASAS) from 2006 only 7\% of respondents thought that gay sex was not wrong at all, while a majority of South Africans (78 per cent) believed it was always wrong and a further $9 \%$ thought that it was wrong to some degree (South African Social Attitudes... 2006: 52). According to South African Social Attitudes Survey (SASAS) from 2010, high scores of respondents indicate conservative attitudes towards sexuality, signifying that the respondent is more likely to believe that pre-marital sex, extra-marital sex and homosexuality are wrong. $78 \%$ felt that sexual relations between adults of the same gender were "always wrong" (South African Social Attitudes... 2010: 35, 186).
} 
were imagined as belonging to South Africa's new democracy. Henriette Gunkel in The Cultural Politics of Female Sexuality in South Africa (2010), presents the specific focus on the rise of homophobic discourses in post-apartheid South Africa.

\section{Gay/lesbian art - some cases}

In South African context both women/feminist artists and LGBT artists have historically existed outside the mainstream art world. This position has given them a unique perspective to comment on a range of themes and issues from apartheid and racial divided society to pertaining to gender, identity and society in their art. In my view in post-apartheid South African society it is still an art of marginalized communities which are weaker and somehow subordinated to male domination. South African art (Williamson and Jamal 1996; Williamson 2004), since the late 70s and 80s, has been dominated by images and issues related to the liberation struggle against apartheid. Given that cultural boycotts and international isolation negatively affected art production until South Africa's reintroduction into the global art community, the internal politics of the country were the overarching themes reflected in South Africa's art. Resistance to oppression, especially in relation to the Apartheid struggle, was vital to the transformation that occurred after 1994. The socio-political climate changed, and the sense of freedom that emerged has since been reflected in the visual arts. The themes that have subsequently emerged focus on identity formation and personal responses to historical inequalities. In particular, the visibility of gay males in South African society is also reflected by the foregrounding of male bodies in artworks after 1994 (Matabeni and Pereira 2014:7-8, Matabeni 2014: 56-60; Marx 2014: 29-30). This date marked a turning point in South African history for homosexuals as the decriminalization of homosexuality created a political climate that was free from legal discrimination.

Today many contemporary artists research interests are primarily concerned with exploring identity, specifically lesbian/gay identity and strategies of visual representation within the modern South African context. Although their forms of expressions are different they love to shock audience.

One of the leading artists related to the field of Queer Theory - Steven Cohen (b. 1962) is especially famous for one of his works which depicted president Nelson Mandela in a large white wig in a Marie-Antoinette parody, with the infamous speech bubble: "Let them eat cock." It is also a fitting portrait of an early 1990s 'gay liberation' movement in South Africa (Van Rensburg 2004). By 1997 Cohen had begun to try performance art, dressing up in inventive and outrageous costumes, binding his penis, inserting sparkler fireworks in his anus, and 
staggering on heels constructed from antelope oryx horns. His costumes, often exposing large parts of his body, can be described as membranes implying elements of a 'female' appearance and also as a counteraction with his male body. Phallic symbols such as dildos and also his own genitals play a central role in some of Cohen's performances. The artist himself explained in an interview that he used his penis, because "[...] it's me. Everything about me is inscribed in my penis - white, Jewish, male, gay. It's about identity, it's not about fucking" (Cohen 2014).

Cohen rapidly became more (of an) activist in his approach, bravely carrying his in-your-face creations right into the enemy camp: at macho events like rugby matches, horse races, dog shows, Afrikaans political rallies. In an interview that was uploaded on the internet platform Youtube on March 11, 2014, he concentrates on a piece he performed in Paris in 2013 (Coq/Cock), for which he was later arrested and charged guilty for sexual exhibitionism (Cohen 2014). In the interview, by referring to his penis as being an essential part of the performance, Cohen discloses several central themes of his work. Sex, sexuality, religion, gender and the questioning of it can repeatedly be found in Cohen's performances.

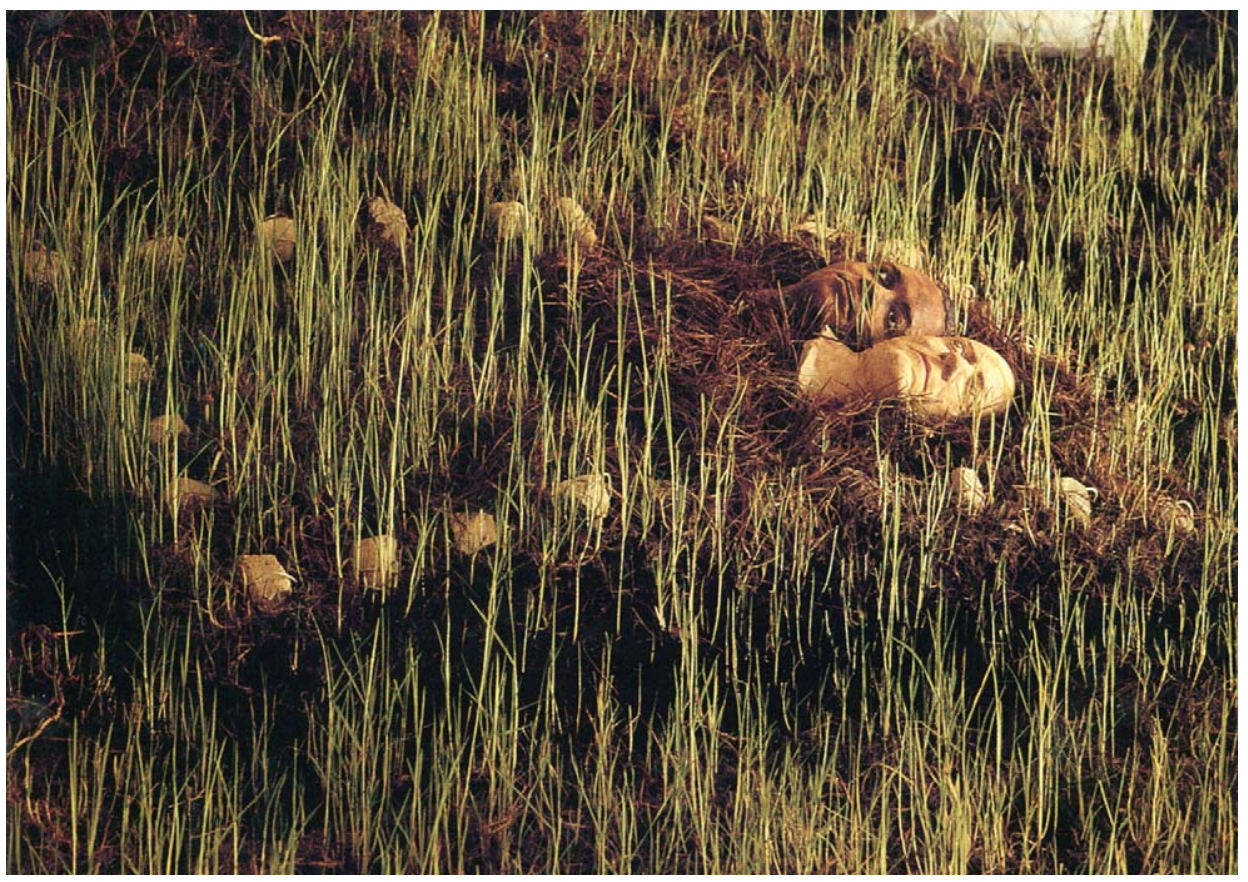

Figure 1. Clive van den Berg, Masks of Van den Berg and his lover form part of Men Loving, on "Faultlines", in the Cape Town Castle, in November 1997. Image courtesy of the Artist 
Moreover, the artist focuses on his skin color, racism and politics. Death, as well as the decomposition of the body, may be found as elements in Cohen's performances. As previously mentioned, his work is multilayered. Therefore, it seems practical and logical to study the artist's oeuvre from different angles. Cohen's work, of course, is rooted in the experience of the queer, the monster outsider whose societal destiny and role it is to out-freak as much as freak out. Cohen leaves his works open for a range of different reactions or interpretations: admiration, anger, a transposed humiliation, confusion, wonder, fear, or even the reactionary attempt to censor. Rarely is there the confidence of a mutually conclusive understanding. His body works, or performances, pushed these earlier concerns even further, and his direct interactions with the public has been an ongoing project of immense courage, creativity and dare one say, beauty.

Other than Cohen, Clive van den Berg's (b. 1958) oeuvre is also responsive to and comments on homosexual experience; some might also claim that his sexual orientation is not as important as material for content. A concern for human rights and more specifically gay rights has always underpinned his work, which deals with unwritten history and with the intersections of space, memory and identity. In his controversial installation, which was part of his Memorials without Facts/Men Loving (1996) project, he presented a vivid marker of the shift from one cultural and political regime to another, during the very year the new constitution was enacted. Van den Berg presented the busts of two male lovers one white and one black. These busts, which look like rejects or escapees from a museum, are angled at a tender proximity to each other forming a resonant image interracial male romantic intimacy. A bed was burnt into the grass, a black halo encompassing the lovers. Stranded on the green slope were white paper constructions of a ship and a gaping suitcase, spilling rocks. Under the tide Men Loving, notes read: "In 1735, two men were taken into the Bay off Cape Town when the ship was near Robben Island. They were made to 'walk the plank' while chained together. They had loved each other." A gap follows, and then: “On Friday May 8 we adopted a constitution which forbids discrimination on the basis of sexual preference. Perhaps now loving will be easier." The two heads are casts, apparently of the heads of Van den Berg himself and his former lover, but Men Loving references a real court case from 1735 in which two men, a Khoikhoi herder and a Dutch sailor who had long shared a sexual relationship on Robben Island, were executed for sodomy. This fugitive relationship thus reaches the present only through the traces its punitive encounter with the law left in official documents (Munro 2012: 59). Van den Berg's phrase "memorials without facts" is clearly a reflection on the difficulties of unearthing histories of clandestine desire and the subsequent imaginative work done in the present to "flesh out" the historical record. It is worth mentioning that in 2005 Van den Berg and his beloved 


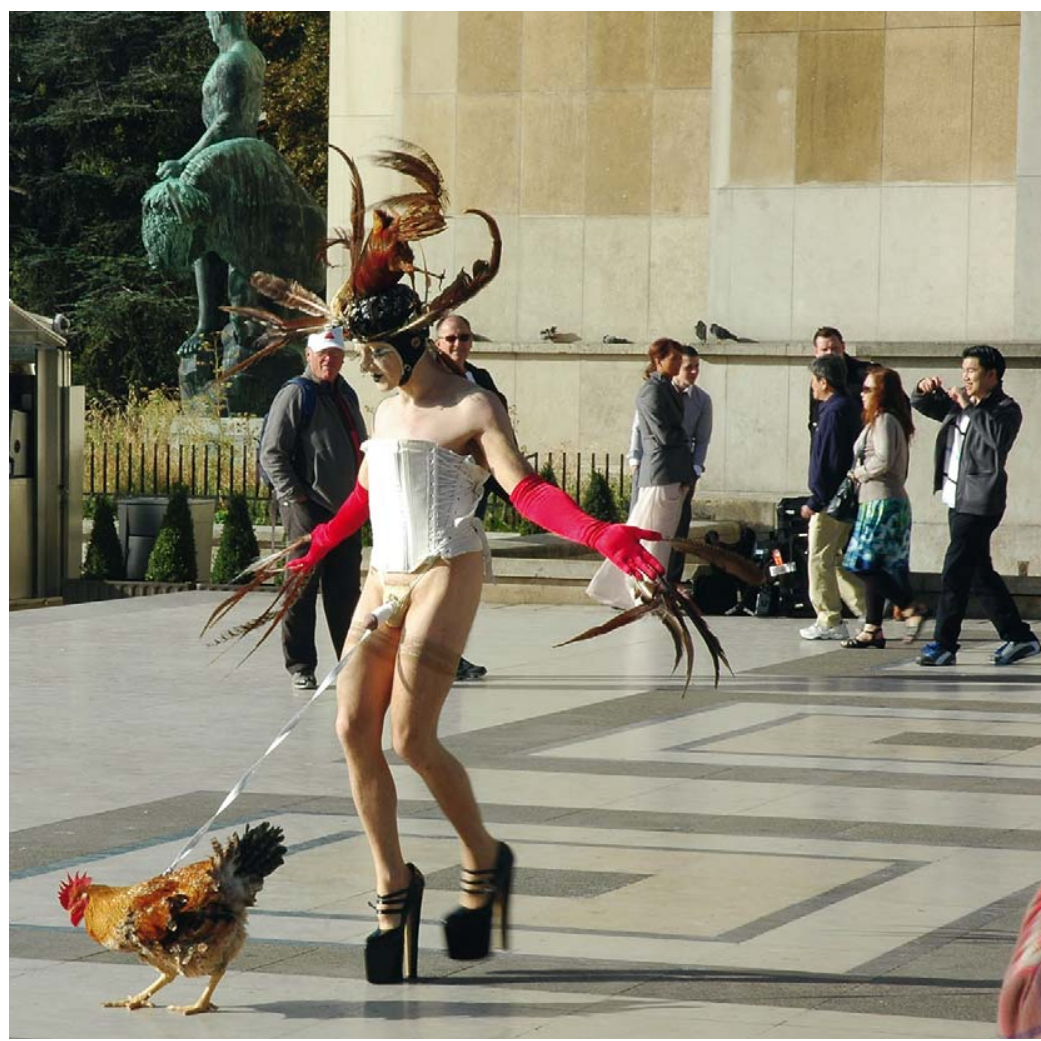

Figure 2. Steven Cohen, Performance Coq/Cock, Paris in 2013. Image courtesy of the Artist

one - musician Rocco de Villiers were recognized the most famous gay couple in South Africa (Stern 2005).

In the same vein, one could describe Andrew Verster's (b. 1931) paintings from his Erotic Interiors (1996) series - a scene of two men kissing or gigantic figures of naked men from Expulsion (1987). The medium of oil painting was exploited by Verster to showcase the freedom of artistic expression in the context of a post-apartheid South Africa. Verster's fascination with placing the male body in the interior, private space highlighted some of the issues concerned with representing the male body by a gay male artist.

Black artist Nicolas Hlobo (b. 1975) similarly to Cohen, wishes to shock and shake up his viewers. In his first exhibition entitled Izele, or birth, the key work was the sculpture Ndiyafuna (2006). Ndiyafuna means in Xhosa "I am searching," or "I long for." This title, in combination with the male figure bending over and with trousers partly down, together with the knowledge that Hlobo 
is homosexual, produces an immediate sexual association. The man featured in this statue is searching for his identity; he wants to have a life that fits in with both being a homosexual and a member of the Xhosa community. As the artist states: "It's looking at the idea of searching for or concealing one's identity. And it makes reference to certain fashion trends. The teenagers who are into hip-hop wear their pants halfway down their buttocks with their boxers revealed - something that is very challenging to older people! And the kids, when they dress like that, they feel very good about it" (Williamson 2009: 132).

According to the opinion of South African artist and art curator - Sue Williamson, Hlobo's work, through the of use of Xhosa titles (without any translation) overturns the prevailing linguistic power structures that aid in shaping the concept of an art gallery, a cultural space largely dominated by white artists and audiences (Ibidem). Williamson implies that Hlobo's titles present, points of denial or entry into his work, depending on one's ethnic affiliation (Williamson 2009: 132). In the gallery space, Hlobo simultaneously evokes the conflicts between the private and the public spheres, the traditional and the modem lives and the normative and the taboo.

White artist and photographer Jean Brundrit (b. 1966) from Cape Town, concentrates on exploring lesbian identity and its strategies of visual representation

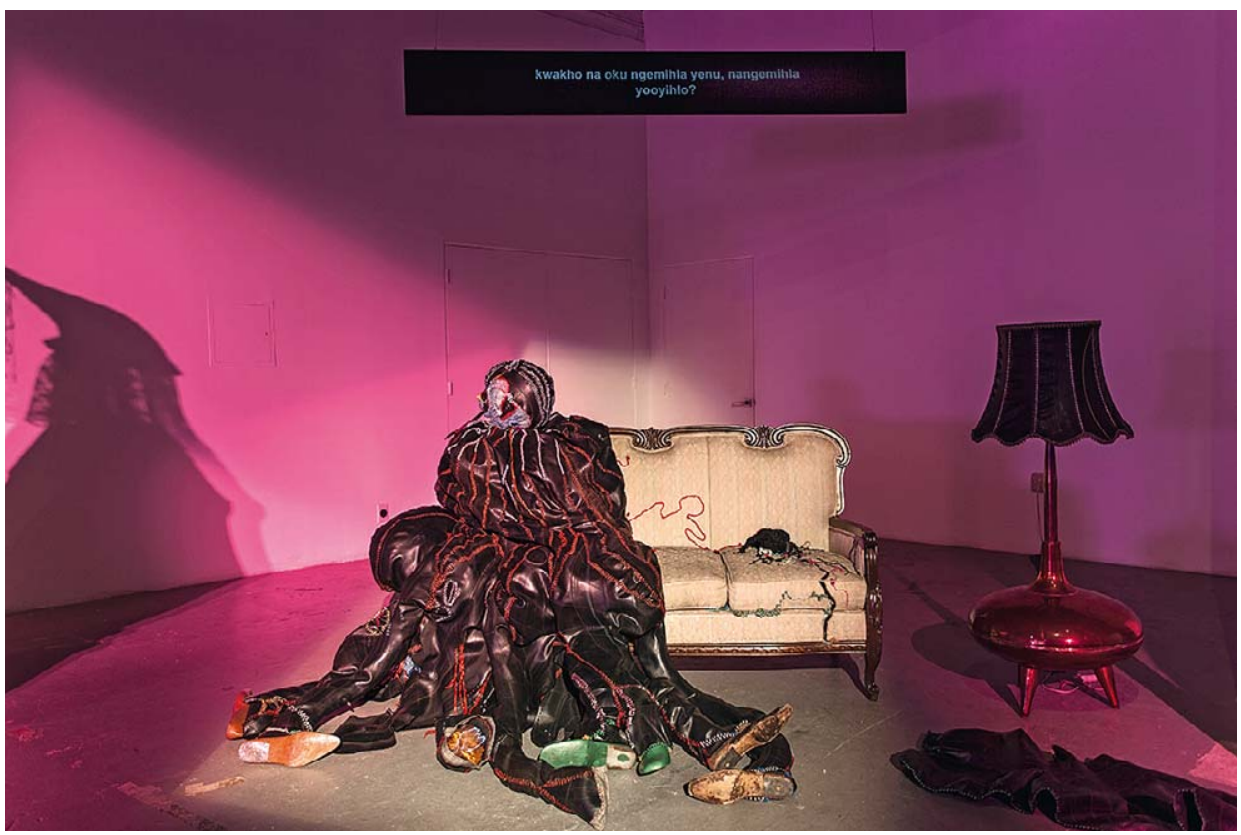

Figure 3. Nicholas Hlobo, Intethe ("Locust" in the Xhosa language), Miami 2013. @Terremoto Mexico 
within South African context. One of her early works presents problems of lesbians in society - Portrait of a Lesbian Couple in South Africa (1995) shows a suburban setting with a lesbian couple erased and a white space outlined where their identity should have been revealed. By taking on lesbian and feminist concerns, and highlighting these areas of discrimination, she questions prejudice in more general terms. In this work she illustrates an issue that although South Africa has a liberal constitution, which recognizes equal rights regardless of gender and sexual orientation, in reality the majority of South African citizens still live in an intolerant and homophobic society. Through making works that foreground lesbian issues she is not trying to be didactic or to convert anybody but rather wants to make people think about the invisibility of lesbians in the whole South African society (Josephy 2004). In group of photographs produced in 1999 - Does Your Lifestyle Depress Your Mother? She deals with the subject of the 'ordinariness' of lesbian lives. The reason for the creation of this work was the fact that, Brundrit discovered that the only images of lesbians commonly found in the South African media were porn images designed for a heterosexual male audience. The artist maintains that: "I wanted to show 'real' lesbians," and explains: "By not showing anything hardcore, I've taken away the voyeuristic angle that might have otherwise been there for the viewer" (Gunkel 2010: 141).

In the exhibition "Out of site" at the AVA Gallery in Cape Town in 2013, Brundrit showcased the series, The Space Inside. The series features close-up portraits of lesbian-identified women against stark black or white backgrounds rendered in high detail, a gentle halo of light encircles the faces, exemplifying each facial feature; every fold, wrinkle, and imperfection is laid bare and visible. Despite the simplistic presentation of her subjects, the soft facial expressions beckon the viewer into an intimate dialogue. Brundrit silently interjects in this initial dialogue between subject and viewer by choosing to capture the moment when the participants' eyes are closed; she isolates and unsettles one of our most essential senses, vision, to raise questions about lesbian subjectivity.

By fixating on the absence of gaze, Brundrit engages in a queer gaze that unsettles the traditional hierarchy of gazes between the dominant viewer and powerless subject - through intimate portraiture, she narrows the space between the subject and audience and challenges viewers to participate in a process of introspection. The Space Inside, compels the viewer to consider the implications of relying on vision to demarcate our position in relation to those around us.

Furthermore Brundrit is also an active participant of scientific conferences e.g. her visual presentation entitled "The Lesbian Lived Experience in South Africa," at the conference Lesbian Lives XVI: Representations of the Lesbian in Art, Culture and the Media in 2009 in Dublin and a conference paper "Speaking OUT: Strategies of Representing Complex Lesbian Identities in South Africa," presented 
at the conference Home/Land: Women, Citizenship and Photographies at Loughborough University in 2012. In her academic papers she points out various aspects of lesbian life and how Lesbians are perceived in society because "Identity is often about reflection," says the artist (Josephy 2004).

One of the most interesting manifestations of contemporary South African Art, connected with the gender subject matter, are the photographic and multimedia works of Zanele Muholi (b. 1972). She is one of a handful of black women artists who figure prominently in the visual arts field, and her work has been shown both in South Africa and abroad (her work could be seen in shows in London, Liverpool, Rome, Basel, Ulm, and San Francisco (Stevenson 2017). It is undeniable that Muholi is certainly the most visible black lesbian artist in South Africa, and has received numerous awards for her work. ${ }^{12}$ However her photographs have also generated a great deal of controversy. In August 2009, South Africa's Minister of Arts and Culture, Lulu Xingwana, walked out of an exhibition that contained several of Muholi's photographs on the grounds that they were "immoral, offensive" and worked "against nation-building." This has placed Muholi's photographs at the center of a national debate ${ }^{13}$ about homophobia, freedom of expression, and queer experience (Thomas 2014: 35).

This female artist portrays lesbian relationships in their extreme carnal and physical dimensions e.g. cycles of colour photos entitled "Initial Series" or "Faces and Phases." In her most important works such as Aftermath (2004) and Hate Crime Survivor (2004), Muholi documents the tragic and shocking realities of so called "corrective rape" in South African townships - a practice whereby lesbian woman are repeatedly raped in an attempt to turn them into "real African women." Black-and-white photography entitled Aftermath (silver gelatin print $600 \times 395 \mathrm{~mm}$ ) presents an image of an unidentified woman, from her lower torso to just below her knees. The woman is only wearing underpants bearing the label Jockey, which can be read as a signifier of lesbian identity. Her hands, at the center of the picture, are covered over her genitals. There are different possible readings of the image but Muholi guides the viewer by including a caption which states the following: "[m]any lesbians bear the scars of their difference, and those scars are often in places where they can't be seen."

The title alone offers little to go on: this woman has clearly been the victim of a trauma, an injury to her body a viewer's attention is drawn to a long scar that runs vertically down the woman's right thigh, from her groin to just above her knee. In denying women subjectivity (in many of her works) by the exclusion of

\footnotetext{
${ }^{12}$ Zanele Muholi holds numerous awards for her photography, including the recent Freedom of Expression Index Award, Tollman Award for the Visual Arts, the Casa Africa award for best female photographer, and a Foundation of Blachère Award.

${ }^{13}$ For more details please check footnotes 3 and 10.
} 
any facial features, Muholi not only suggests that these women might continually fear recognition in their communities, but also that they remain ignored by the greater powers that be. In Henriette Gunkel powerful interpretation Aftermath can be seen as a metaphor for the historical and contemporary discourses of (neo)colonial sex/gender organizations. The first scar, the one that is visible on the thigh, is healed but will nevertheless remain visible on the body: it will always mark the black body in the image. This scar, therefore, can be read as the signifier for the violations of the black body through colonial discourses, particularly those that targeted the black female body for European self-identification and gratification. Within the construction of the European Self it was the supposedly availability of African women, in particular, that was taken for granted and was thus constituted as such, finding its most crude expression in the act of rape (Gunkel 2010: 136). This interpretation has deeper historical reasons as Nicholas Monti has pointed out, the colonial invasion of the land was often associated with the conquest of the woman:

"The seduction and conquest of the African woman became a metaphor for the conquest of Africa itself [...] to both were attributed the same, irresistible, deadly charm" (Monti 1987: 72). This point is underscored by what is possibly the most telling and poignant work in terms of "hate crime survivor," - Case Number (2004 silver gelatin print 385 × 255mm), which shows an impersonal, carelessly written number for a case of "rape and assault" on a piece of paper which has clearly been crumpled many times by the wringing of anguished hands.

Dada ${ }^{14}$ (2003, silver gelatin print,485 x 300mm), is another standout piece done by Muholi. Black and white photography shows a young woman wearing a pale strap-on dildo covered in a condom. The title refers not only to roles that Muholi's subjects either chose to take on, or positions of power they are denied through their 'lack' of a (white) penis. The work also references the early Modernist art movement that founded an art history around a selection of Western Masters, ignoring the visual and critical voices of both women and Africans. The useless condom in Dada also bemoans the lack of education and interest in finding a means towards promoting safe sex between women. By altering meaning and placing something where it does not belong, Muholi forces the viewer to imagine the unimaginable even within a country struggling to get to grips with a transforming society, a post-apartheid society.

In 2009 Zanele Muholi founded a non-profit organization called Inkanyiso which aims at supporting visual arts and the presence in the media of the South

${ }^{14}$ The title Dada invokes further meaning that at best is associated with the cultural avant-garde movement that emerged in Europe in the early $20^{\text {th }}$ century. The origin and various meanings of the word "Dada" present us with possibilities to read further into Muholi's photograph. The translation of "Dada" as found in the French dictionary, a "hobby-horse," reaffirms the dildo as a toy, a play-thing or something that mimics another thing, in this case the hetero-phallic authority. 


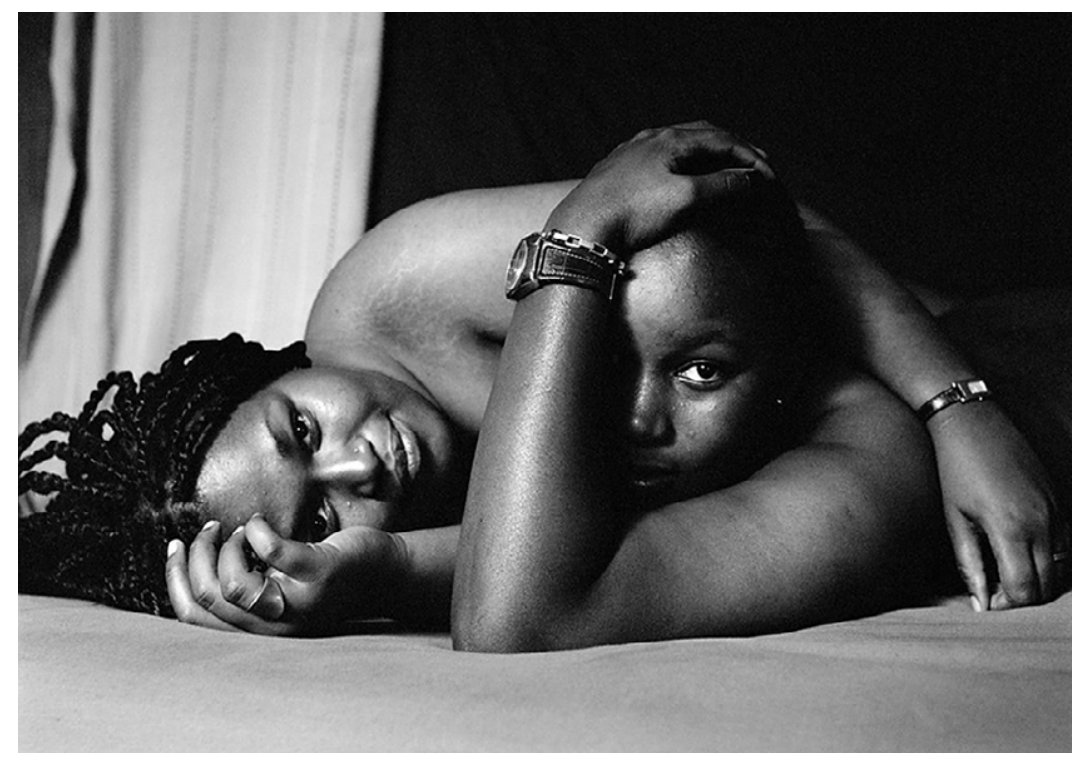

Figure 4. Zanele Muholi, Apinda Mpako and Ayanda Magudulela Parktown Johannesburg, from Being series, 2007 (silver gelatin print. Image size 76.5 x $76.5 \mathrm{~cm}$ ). ( $)$ Zanele Muholi. Courtesy of Stevenson, Cape Town/Johannesburg and Yancey Richardson, New York

African LGBT community. Muholi states "As an insider within the black lesbian community and a visual activist, I want to ensure that my community, especially those lesbian women who come from the marginalized townships, are included in the women's 'canon'." (Van Wyk 2010). In 2010 the South African Broadcasting Corporation - SABC station ordered for production a documentary film entitled Difficult Love and it was directed by the very same artist Zanele Muholi and Peter Goldsmid. This film portrayed the personal challenges undertaken by the artist and other black lesbians in South Africa. The problems introduced in this documentary film relate to very personal matters such as pregnancy in lesbian relationships or the problems of disclosing their true orientation. Though in comparison with other African countries the South African democracy seems particularly tolerant and Cape Town is even often considered to be an 'African Gay Paradise,' some parts of this large country still remain quite dangerous for homosexuals. In municipal ghettos and in rural areas, lesbians often become victims of the socalled "corrective rapes" and are the subjects of rejection by the community. The film also presents serious assessment and evaluation of this artist's controversial works by the South Africans art critics (Van Wyk 2010). It can be assume that Muholi hopes to inspire the viewer to reconsider the judgments and prejudices that may occur in interactions with lesbian and transgender people. 


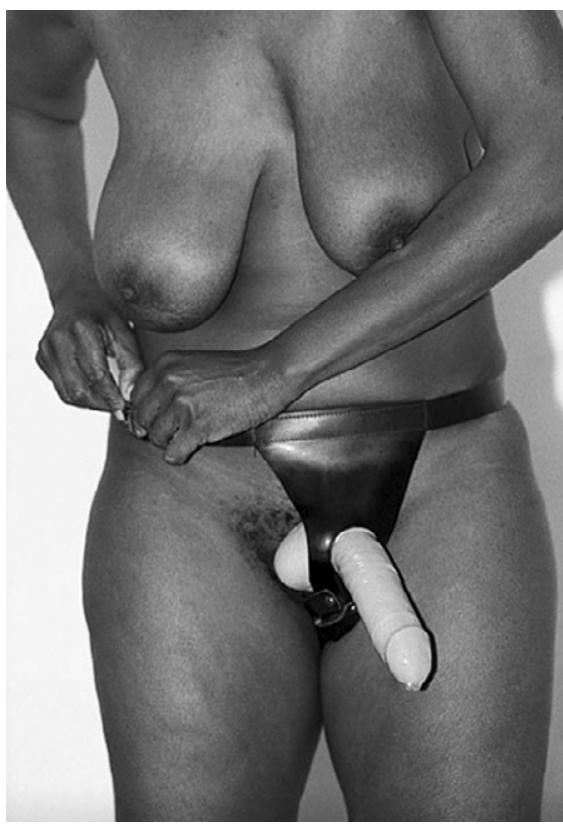

Figure 5. Zanele Muholi, Dada 2003, (silver gelatin print. Image size $48,5 \times 30 \mathrm{~cm} \odot$ Zanele Muholi. Courtesy of Stevenson, Cape Town/Johannesburg and Yancey Richardson, New York

The problems of gender in the African world are inseparably connected with the threat of the AIDS pandemic, which in South Africa similarly as in other countries of the African continent is a very serious social problem. This topic of AIDS is undertaken by many artists in their works, from little-known (like Bambani Women's Group ${ }^{15}$ (Williamson 2009: 126-127)) or absolute anonymous poster makers and mural artists, to prominent artists and freedom activists such as the very well-known Sue Williamson (From the Inside 2003) and Clive van den Berg (Love's Ballast 2004). All these works became the stage for an allegory of the ravages of AIDS, which has devastated the country at the turn of the $20^{\text {th }}$ century. However, the broader analysis of this artistic phenomenon exceeds the objectives of this article.

Artistic activity as cultural production is a framework for society and the innovative capacities of the arts must be harnesses in the face of "increasing uniformity of the life of individuals in the urban context" (Guattari 1995: 152). Today South African gender oriented visual art is characterised by a hegemony

\footnotetext{
${ }^{15}$ The Bambanani Women's Group went on to work on the Longlife Project, which raised awareness and campaigned for antiretroviral treatment to be made available in the South African public health care sector. The Longlife Project recorded in artistic the life stories of the women who were participating in a Medésins Sans Frontières (MSF) pilot antiretroviral programme.
} 
of heterosexual stereotypes which occupy a dominant place in the society and it emerges from within the gaze of desire which is increasingly often communicated only as image than as text. These images are presented as complex and multi-layered visual signifiers. Gender identity is not immune to this controlling gaze, or its commercialised forms, which represent the dichotomy of male or female as the central foundation stone of society. Still, many people are opposed to behaviour associated with open displays of homosexual sexuality. The most famous controversial case is, current South African President Jacob Zuma, who was among most outspoken opponents of homosexual sexuality. In 2006 he claimed that "(...) when I was growing up, an ungqingili (a derogatory Zulu term describing a homosexual) would not have stood in front of me. I would knock him out" (Zabus 2014: 43). Therefore it is not surprising that Zanele Muholi exposes the gapping contradictions between the South African constitutional protections of LGBTI citizens drafted twenty years ago and the reality on the ground in her community. And as her artist statement she says, "In 2014, when South African democracy celebrates its 20 years, it seems more important than ever to raise again our voice against hate crimes and discriminations made towards the LGBTI community" (Muholi 2014).

\section{Bibliography}

Aina, Olabisi. 1998. "African Women at the Grassroots: The Silent Partners of the Women's Movement." Sisterhood, Feminisms, and Power: From Africa to the to the Diaspora. Ed. Obioma Nnaemeka. Trenton, NJ: Africa World Press. 80-93.

Arndt, Marlene, and Gideon de Bruin. 2006. "Attitudes Toward Lesbians and Gay Men: Relations with Gender, Race and Religion Among University Students." PINS [Psychology in Society] (33): 16-30.

Berman, Esmé. 1973. Art \& Artists of South Africa: An Illustrated Biographical Dictionary and Historical Survey of Painters, Sculptors E Graphic Artists Since 1875. Cape Town: A.A. Balkema.

1993. Painting in South Africa. Halfway House: Southern Book Publishers. . 2010. Alexis Preller: Africa, the sun and shadows. Johannesburg: Pan Macmillan.

Botha, Kevan, and Edwin Cameron. 1997. "South Africa." Sociolegal Control of Homosexuality: A Multi-Nation Comparison. Eds. Donald J. West, and Richard Green. New York: Plenum Press. 23-26.

Cock, Jacklyn, and Alison Bernstein. 2002. Melting Pots and Rainbow Nations: Conversations about Difference in the United States and South Africa. Illinois: University of Illinois Press.

Cohen, Steven. 2014. Sexual Exhibitionism or Performance Art? 30 May 2016. <https:// www.youtube.com/watch?v=xsx9gtQM8f8>.

Croucher, Sheila. 2002. "South Africa's Democratisation and the Politics of Gay Liberation." Journal of Southern African Studies. 28(2): 315-330. 
Davis, Whitney. 1994. Gay and Lesbian Studies in Art History. Binghamton, New York: Haworth.

Elder, Glen. 1995. “Of Moffies, Kaffirs and Perverts: Male Homosexuality and the Discourse of Moral Order in the Apartheid State." Mapping Desire: Geographies of sexualities. Eds. David Bell, and Gill Valentine. London and New York: Routledge. 50-58.

Epstein, Helen, and Rachel Jewkes. 2009. "The Myth of the Virgin Rape Myth". The Lancet 374(9699): 1419.

Essof, Shereen. 21 Feb. 2012. South Africa: Patriarchy, Paper, and Reclaiming Feminism. 31 May 2016. <https://www.opendemocracy.net/5050/shereen-essof/south-africa-patriarchy-paper-and-reclaiming-feminism>.

Fihlani, Pumza. 30 June 2011. “South Africa's lesbians fear 'corrective rape.'” 1 Nov. 2013. <http://www.bbc.co.uk/news/world-africa-13908662>.

Gevisser, Mark. 1995. "A Different Fight for Freedom. A History of South African Lesbian and Gay Organisation from the 1950s to the 1990s." Defiant Desire: Gay and Lesbian Lives in South Africa. Eds. Edwin Cameron, and Mark Gevisser. New York and London: Rutledge. 14-86.

Goodman, Ryan. 2001. “Beyond the Enforcement Principle: Sodomy Laws, Social Norms, and Social Panoptics." California Law Review 89(3): 643-740.

Guattari, Felix. 1995. Chaosmosis: An Ethico Aesthetic Paradig. Trans. P. Bains and J. Pefanis. Sydney: Power Publications.

Gunkel, Henriette. 2010. The Cultural Politics of Female Sexuality in South Africa. London: Routledge.

Hunter, Mark. 2010. Love in the Time of AIDS: Inequality, Gender, and Rights in South Africa. Bloomington and Indianapolis: Indiana University Press.

Itano, Nicole. 2003. "South Africa Begins Getting Tough on Rape." The Star 2(24): 4.

"Jacob Zuma Gives Cautious Support for Gay Marriage." 14 Dec. 2012. 6 May 2017. <http://www.gaystarnews.com/article/jacob-zuma-gives-cautious-support-gay-marriage141212/>.

Jordaan, Roxanne. 1987. "The Emergence of Black Feminist Theology in South Africa." Journal of Black Theology in South Africa 1(2): 42-46.

Jordaan, Roxanne, and Thoko Mpumlwana. 2015. “Two Voices on Women's Oppression and Struggle in South Africa." Feminist Theology from the Third World. Ed. Ursula King. Oregon: Wipf and Stock Publishers. 150-169.

Josephy, Svea 2004. "Jean Brundrit." Artthrob (79)3. 2 July 2016. <http://artthrob. co.za/04mar/artbio.html>.

Lewis, Sharon. 1994. Dealing with Rape. Johannesburg: Sached Books.

Livermon, Xavier. 2013. "Queer(y)ing Freedom: Black Queer Visibilities in Post Apartheid South Africa." A Journal of Gay and Lesbian Studies 18(2-3): 297-323.

Marx, Jacqueline. 2014. "Negotiating Homosexual in/Visibility." Reclaiming Afrikan: Queer Perspectives on Sexual and Gender Identities. Ed. Zethu Matabeni. Athlone: Modjaji Books. 29-32.

Matabeni, Zethu. 2014. "How not to write about queer South Africa." Reclaiming Afrikan: Queer Perspectives on Sexual and Gender Identities Ed. Zethu Matabeni. Athlone: Modjaji Books: 56-60

Matebeni Zethu, and Jabu Pereira. 2014. "Preface." Reclaiming Afrikan: Queer Perspectives on Sexual and Gender Identities Ed. Zethu Matabeni. Athlone: Modjaji Books: 7-10. 
Mbuy-Beya, Bernadette. 2005. "Human Sexuality, Marriage, and Prostitution." The Will to Arise: Women, Tradition, and the Church in Africa. Ed. M. Amba Oduyoye. Eugene: Orbis. 155-180.

Monti, Nicholas. 1987. Africa Then: Photographs, 1840-1914. New York: Knopf.

Moodie, Dunbar T, Ndatshe Vivienne, and British Sibuyi. 1988. "Migrancy and Male Sexuality on the South African Gold Mines." Journal of South African Studies 14(2): 228-256.

Muholi, Zanele. 2010 "Faces and Phases." Safundi: The Journal of South African and American Studies 11(4): 407-420.

2014. Of Love E Loss. Stevenson. 2 July 2014. <http://www.contemporaryand. com/exhibition/zanele-muholi-of-love-loss/>.

Munro, Brenna M. 2012. South Africa and the Dream of Love to Come: Queer Sexuality and the Struggle for Freedom. London/Minneapolis: University of Minnesota Press.

Nasimiyu-Wasike, Anne. 2004. “Christology and an African Woman's Experience." Liberation Theology: An Introductory Reader. Ed. C. Cadorette et al. Eugene, Oregon: Wipf and Stock Publishers. 92-103.

Owens, Craig. 1998. "Dyskurs Innych: feministki i postmodernizm." Postmodernizm. Antologia przekładów. Ed. R. Nycz. Kraków: Wydawnictwo Baran i Suszczyński. 421-451.

Pandit, Shereen. 2002. "Women and Oppression in South Africa." Journal of Gender Studies 11(1): 67-78.

Ratele, Kopano, and Norman Duncan. 2003. Social Psychology: Identities and Relationships. Landsdowne: Juta and Company Ltd.

Rensburg, Storm Janse van. 2004. "Archive Dive: Sailing Forth." ArtThrob 79(3). 1 May 2016. <http://www.artthrob.co.za/04mar/reviews/pink_vanrensburg.html>.

SAPA [South African Press Association]. 2012. "ANC Distances Itself from Gay Comments." 6 June 2017. < http://www.iol.co.za/news/ politics/anc-distances-itself-from-gay-comments-1290046/>.

South African Social Attitudes Survey. Changing Times, Diverse Voices (SASAS). 2006. Eds. Udesh Pillay, Benjamin Roberts, and Stephen Rule. Cape Town: HSRC Press.

South African Social Attitudes Survey. Reflections on the Age of Hope (SASAS). 2010. Eds. Benjamin Roberts, Mbithi wa Kivilu, and Yul Derek Davids. Cape Town: HSRC Press.

Stern, Nathaniel. 2005. “ Implicit Art Archives." 1 May 2016. <http://nathanielstern. com/blog/2005/10/18/the-most-famous-gay-couple-in-south-africa/>.

Stevenson. 2017. Zanele Muholi. Biography. 6. June 2017. <http://www.stevenson.info/ artist/zanele-muholi/biography>.

Tamale, Sylvia. 2011. African Sexualities: A Reader. Cape Town: Pambazuka Press.

“Thabo Mbeki Compares Laws Against Gays to Apartheid." n.d. 2 May 2017. <http:// gbmnews.com/wp/archives/710>.

Thomas, Kylie. 2014. Impossible Mourning: HIV/AIDS and Visuality After Apartheid. Lanham: Bucknell University Press.

Thompson, Leonard. 2001. A History of South Africa. III edition. New Haven and London: Yale University Press.

Williamson, Sue. 2004. Resistance Art in South Africa. Cape Town: David Phillip. 2009. South African Art Now. New York: Collins Design.

Williamson, Sue, and Asraf Jamal. 1996. Art in South Africa. The Future Present. Johannesburg: David Phillip. 
Wyk, Lisa van. 2010. "Xingwana: Homophobic Claims 'baseless, insulting.'” Mail \& Guardian Online. 2 July 2016. <https:// mg.co.za/article/2010-03-05-xingwana-homophobic-claims-baseless-insulting $>$.

Zabus, Chantal. 2014. “'Writing with an Accent': From Early Decolonization to Contemporary Gender Issues in the African Novel in French, English, and Arabic." Language and Translation in Postcolonial Literatures, (Routledge Research in Postcolonial Literatures). Ed. Simona Bertacco. New York and London: Routledge. 32-47. 